\title{
Review
}

\section{Puzzling identities}

Vincent Descombes (translated by Stephen Adam Schwartz)

Cambridge, MA: Harvard University Press, 2016, viii + 211pp.,

ISBN 978-0-674-73214-8

Contemporary Political Theory (2019) 18, S191-S194. https://doi.org/10.1057/s41296018-0202-y; published online 20 February 2018

Puzzling Identities is a puzzling book. Having read it carefully, I am still a bit unclear what kind of book it wants to be. At the start, Descombes announces that his aim is to explore the meaning of identity in the contemporary world, whereas in times past identity exclusively meant 'that there is only a single selfsame thing where one might have thought there to be two ... in the past few decades it has come to mean something completely different - that there is a thing that has the virtue of being itself even though it might well have no longer been or not yet become itself' (p. 5, emphasis in original). (The opacity of this phrasing, translated from the French of course, is characteristic of the book.) The book consists of six chapters that discuss various aspects of identity: personal identity, both in the metaphysical sense of continuity of the person over time and in the individualistic sense of something we strive to achieve; related to the latter, phenomena such as identity crises and plural identities; various aspects of collective identity, including the ontological status of collectives such as nations and the normative demands made by proponents of a multicultural politics of identity.

What each of these chapters in itself actually argues, however, is more difficult to determine. The genre of the book is also a puzzle. On the one hand, it seeks to offer a fresh view on identity, and it includes engagements with contemporary philosophers of identity such as Amartya Sen, Charles Taylor and Cornelius Castoriadis. At the same time, it makes very selective use of these writers. For example, in the discussion of multiculturalism and identity politics, no reference is made to a single contemporary writer on the topic, not even Amartya Sen or Charles Taylor, whose work is discussed in a different context. At the same time, there are erudite discussions of historical philosophers, including Aristotle, Pascal, Voltaire and Hegel, but the book does not present itself as a contribution to the history of ideas. There is no systematic genealogy of how identity has changed its meaning over time. The notion that identity represents a problematic category in modernity seems to provide the impetus for the book, but I'm not sure on what terms Descombes seeks to respond to this challenge. I'll illustrate this by saying a

(c) 2018 Macmillan Publishers Ltd., part of Springer Nature. 1470-8914 Contemporary Political Theory Vol. 18, S3, S191-S194 www.palgrave.com/journals 
little more about two of the larger themes the book addresses: plural identities and collective identities.

Identity may well be problematic because in the contemporary era many individuals may be suffering from some sort of identity crisis. Descombes attributes the category of identity crisis to the German-American psychologist and social theorist, Erik Erikson. Erikson arrived at the concept after observing young American soldiers back from World War II, and paralysed by indecision and inaction about the future of their lives (pp. 17-18). In later fieldwork, Erikson traced the distinct moralities to which Native American Sioux adolescents were subject, one traditional, emphasising the sharing of one's wealth, and the other modern American, which stressed by contrast the careful calculation of individual expenditures (p. 19). While previous societies gave their young people formal rites of passage to mark their transition into adulthood, today the task of figuring out their own values is a burden squarely placed on them, leaving young Sioux Americans, like US soldiers returning from the war, disorientated. There are some interesting speculations here about how far the trauma of transformed identity coming to the US as a young immigrant - might have informed Erikson's thinking on the matter. Descombes suggests there is a dualism between our objective identities (as we are seen by society) and the personal identity of individual experience. Erikson's contribution inter alia was to note that the internal perspective I have on myself might not match how others see me (pp. 68-74).

This is true enough, if hardly arresting, but having set the problem up this way, Descombes then leads us into a discussion of Voltaire and Locke on personal identity in the metaphysical sense (pp. 74-87). This is a little bit related to the previous discussion because, if, on the Locke-Voltaire view, the criterion of personal identity in the metaphysical sense is the self-consciousness of being the same person, then the social and personal dimensions of identity can come apart if someone is considered by society to have an enduring identity, but feels herself to have undergone substantial change. But that connection is not made explicitly in the book, and indeed in the next chapter opens by declaring that the twin-identity view leads to an impasse because of the 'lack of any real criterion that would allow us to determine what it is that makes a self the same self as my own' (p. 88, emphasis in original). The chapter then goes to discuss Hegel's view on the matter before an abrupt about-turn back to Erikson and his discussion of Hamlet's crisis of indecision (pp. 92-100). This rather takes us back to where we started. Impasse is indeed the word.

The final two chapters consider the notion of collective identity. Descombes argues that the means by which a group of people can come to comprise a common political identity is through constituting a general will (p. 165). There is some discussion of Rousseau's theory of the general will and his solution to the problem of how future generations, who are not parties to the original contract, can continue to form a single body politic (p. 178). The answer, according to Rousseau, 
according to Descombes, is education of those generations so that they become acculturated with the customs, traditions, and habits of mind of the nation: through common national institutions people become enrolled into the ways of doing things of their polity (pp. 178-180). Although Descombes does not explicitly endorse Rousseau's view, it nonetheless provides the intellectual context against which he discusses multiculturalism and the 'right to difference'. The latter can either be interpreted in 'equistatutory', egalitarian terms, so that the other is recognised as 'like oneself', or in hierarchic terms, where the other has a 'value other than one's own' (p. 184). The latter option involves facing the 'contradictions of "identity politics" since this hierarchy will be put in place in the name of the equality of all citizens' (p. 185).

But this is only a contradiction if the right to difference is conceptualised through the lens of divergent values, as opposed to a universalist demand for equal public recognition, or equality of cultural opportunities and the like. (The latter is indeed egalitarian in ascribing common interests to all citizens, minorities and the majority.) It is here that the lack of engagement with the contemporary multicultural literature is especially evident, as well as Descombes' indebtedness to the French republican tradition, which opposes particular and general interests. The same false dichotomies pervade the discussion of multiculturalism more generally, where Descombes has difficulty appreciating how an individual can have a plural identity 'that has as its awkward effect to require a doubling of the individual' (p. 186). Either the conflicts of plural identity are avoided only by fracturing one's life into separate compartments (p. 187) or one group which forms a person's identity is accorded a primacy so that it encompasses the other(s), which takes us back to the 'republican universalist' solution (p. 187).

But seeing plural identities as necessarily contradictory in this way underappreciates the lived experience of citizens in multicultural democracies across the world, who do accommodate the imperatives of, for example, being a good Muslim and a good citizen of the French republic. And in a larger context, of course, every person has plural identities that they live with and negotiate: in family, in work, in culture and everywhere else. Moreover, the republican universalist solution which posits an ever more encompassing general will faces the difficulty, according to Descombes, that this process never stops: '[o]ver and above our national republic lies the republic of European nations' and eventually the logic of republican universalism presents us with the 'travesty of a cosmopolitanism within a single country' (p. 188). Indeed, not only that, but the general will threatens to eclipse those communities that have a role in the well-being of the encompassing society. All these difficulties only arise because of the republican and Rousseauian terms in which the discussion has been set up. That said, it is never exactly clear when Descombes is proposing his own view and when he is simply reporting the views of others.

두 2018 Macmillan Publishers Ltd., part of Springer Nature. 1470-8914 Contemporary Political Theory Vol. 18, S3, S191-S194 S193 
Perhaps, with my normative political theory background, I have simply misread this book. I've approached it wanting answers to questions of identity, but Descombes may seem himself instead as a kind of intellectual tour guide, taking the reader in hand to traverse the puzzled landscape of identity. If you want an erudite, interesting (though occasionally obscure) guide to how some philosophers have treated identity, then this could be the book for you. But anyone looking for a more systematic historical treatment or a more normative approach will need to look elsewhere.

Jonathan Seglow Royal Holloway, University of London, Egham TW20 0EX, UK j.seglow@rhul.ac.uk 